\author{
Marcin Salamaga \\ Katedra Statystyki \\ Uniwersytet Ekonomiczny w Krakowie
}

\title{
Identyfikacja związków przyczynowych pomiędzy bezpośrednimi inwestycjami zagranicznymi i wzorcem handlu zagranicznego w Polsce
}

\section{Streszczenie}

W literaturze przedmiotu można znaleźć badania nad wpływem bezpośrednich inwestycji zagranicznych na zmiany we wzorcu przewag komparatywnych, jak i struktury handlu zagranicznego. Możliwe są także sprzężenia zwrotne, w których ewolucja wzorca przewag komparatywnych czy przeobrażenia gałęziowej struktury handlu zagranicznego oddziałują na napływ bezpośrednich inwestycji zagranicznych. Można więc zadać pytanie, jaką rolę mają poszczególne zmienne w kształtowaniu wzajemnych powiązań, które z tych powiązań są istotne statystycznie i jaki jest kierunek wzajemnego oddziaływania zmiennych. Odpowiedź może ułatwić badanie przyczynowości w sensie Grangera. Celem artykułu jest ustalenie związków przyczynowych pomiędzy bezpośrednimi inwestycjami zagranicznymi i zmiennymi reprezentującymi konkurencyjność polskiego handlu zagranicznego. W badaniach wykorzystano modele wektorowej autoregresji i testy przyczynowości w sensie Grangera.

Słowa kluczowe: bezpośrednie inwestycje zagraniczne, handel zagraniczny, model VAR, model VECM, test przyczynowości Grangera. 


\section{Wprowadzenie}

Istnieją liczne teorie ekonomii, w których bezpośrednim inwestycjom zagranicznym (BIZ) przypisuje się zasadniczą rolę w kształtowaniu rozwoju gospodarczego. W modelu dynamicznych przewag komparatywnych [Ozawa 1992] wzrost dobrobytu następuje pośrednio poprzez oddziaływanie BIZ na eksport i wzorzec ujawnionych przewag komparatywnych. Rozwój gospodarczy w tym ujęciu modelowym ma charakter ewolucyjny i wspierany jest inwestycjami kierowanymi do kolejnych branż: surowcochłonnej, pracochłonnej, kapitałochłonnej i technologicznie intensywnej, przy czym napływowi BIZ towarzyszą odpowiednie zmiany we wzorcu przewag komparatywnych. Można więc wyróżnić przynajmniej cztery stadia rozwoju gospodarczego ściśle związane z charakterem dominujących BIZ (BIZ surowcochłonne - pierwszy etap rozwoju, BIZ pracochłonne - drugi etap, BIZ kapitałochłonne - trzeci etap i BIZ technologicznie intensywne - czwarty najwyższy etap rozwoju) [Ozawa 1992, Salamaga 2013]. W tym ujęciu teoretycznym bezpośrednie inwestycje zagraniczne traktowane są jako determinanta dla przewag komparatywnych i eksportu. $Z$ drugiej strony możliwe są także sprzężenia zwrotne, w których ewolucja wzorca przewag komparatywnych, czy przeobrażenia gałęziowej struktury handlu zagranicznego oddziałują na napływ bezpośrednich inwestycji zagranicznych. Można więc zapytać o rolę poszczególnych zmiennych w kształtowaniu wzajemnych powiązań: które z tych powiązań są istotne statystycznie i jaki jest kierunek wzajemnego oddziaływania zmiennych? Odpowiedź może ułatwić badanie przyczynowości w sensie Grangera. Celem artykułu jest ustalenie związków przyczynowych pomiędzy bezpośrednimi inwestycjami zagranicznymi i zmiennymi reprezentującymi konkurencyjność polskiego handlu zagranicznego. Istotą tego badania jest też określenie kierunku i siły oddziaływania pomiędzy zmiennymi, co powinno ułatwić dobór instrumentów ekonomicznych wspierających handel zagraniczny bądź stymulujących napływ BIZ. Dodatkowo zbadano wzajemne powiązania pomiędzy wskaźnikami ujawnionej przewagi komparatywnej różnych grup towarów, co pozwoli na pełniejszą identyfikację zmian we wzorcu przewag komparatywnych i ocenę poziomu konkurencyjności polskiego handlu zagranicznego. W badaniach wykorzystano modele wektorowej autoregresji i testy przyczynowości w sensie Grangera. W literaturze przedmiotu można znaleźć wyniki badań powiązań pomiędzy BIZ i innymi wskaźnikami makroekonomicznymi z użyciem tej metodologii. Zwykle ograniczały się one do identyfikacji zależności pomiędzy BIZ, PKB, eksportem czy wskaźnikami rynku pracy w gospodarkach różnych krajów [Hastiadi 2011, Jayanthakumaran i Lee 2007, Sultan 2013]. Stosunkowo mniej liczne są publikacje, w których modele wektorowej autoregresji i testy przyczynowości Grangera stosuje się do badania zależności dla polskiej gospodarki [Gurgul i Lach 2009]. 
Brakuje natomiast opracowań naukowych podejmujących badania dynamicznych zależności pomiędzy komponentami wzorca przewag komparatywnych i BIZ. Niniejszy artykuł w pewnym stopniu może wypełnić tę lukę. Wyniki analizy umożliwią również odniesienie do teorii dynamicznych przewag komparatywnych T. Ozawy, w której główną rolę odgrywają bezpośrednie inwestycje zagraniczne.

\section{Metoda badawcza}

Badania związków przyczynowych poprzedziło przygotowanie danych w postaci kwartalnych szeregów czasowych wartości bezpośrednich inwestycji zagranicznych (BIZ) w Polsce w mln EUR, polskiego eksportu (Ex) w mln EUR, wskaźników ujawnionej przewagi komparatywnej towarów i wskaźnika pokrycia importu eksportem. W obliczeniach posłużono się danymi z Głównego Urzędu Statystycznego obejmującymi okres od pierwszego kwartału 2002 r. do czwartego kwartału 2012 r. ${ }^{1}$ Wskaźniki przewag komparatywnych (revealed comparative advantage - RCA) dóbr o różnym nasyceniu czynnikami produkcji obliczono według wzoru [Misala 2011]:

$$
R C A_{i}=\ln \left(\frac{E x_{i}}{\operatorname{Im}}: \frac{E x}{\operatorname{Im}}\right),
$$

gdzie:

$E x_{i}$ - wartość eksportu $i$-tej grupy towarowej,

$I_{i}$ - wartość importu $i$-tej grupy towarowej,

$E x$ - całkowita wartość polskiego eksportu,

Im - całkowita wartość polskiego importu.

Dodatnia wartość miernika (1) wskazuje na występowanie przewagi komparatywnej w $i$-tej grupie towarowej, natomiast ujemna wartość tego wskaźnika oznacza brak takiej przewagi. Ponadto miernik (1) określa intensywność ujawnionej przewagi komparatywnej: im wyższą wartość przyjmuje, tym wyższy jest poziom tej przewagi. W niniejszych badaniach przewagi komparatywne obliczono dla czterech grup towarów: surowcochłonnych (RCAs), pracochłonnych (RCAp), kapitałochłonnych (RCAk) i technologicznie intensywnych (RCAt). Przydzielenie towarów do poszczególnych grup przeprowadzono na podstawie Międzynarodowej Standardowej Klasyfikacji Handlu (Standard International Trade Classiffication - SITC) na dwucyfrowym poziomie dezagregacji [Misala i Pluciński 2000].

${ }^{1}$ http://www.stat.gov.pl/gus/wskazniki_makroekon_PLK_HTML.htm (dostęp: 10.03.2014). Ograniczenie się do danych z lat 2002-2013 było uwarunkowane dostępnością kompletnych danych kwartalnych. 
W ocenie konkurencyjności eksportu posłużono się również wskaźnikiem pokrycia importu eksportem (trade coverage - TC), który definiuje się jako iloraz wartości eksportu do importu. Miernik ten wyraża wewnętrzną przewagę komparatywną kraju. Wartość wskaźnika TC większa od jedności w określonej branży (grupie towarowej) wskazuje na specjalizację kraju w tej branży [Szymanik 2004].

Badanie związków przyczynowych pomiędzy zmienną BIZ i zmiennymi Ex, RCAs, RCAp, RCAk, RCAt, TC przeprowadzono za pomocą modeli wektorowej autoregresji (vector autoregression model - VAR) oraz wektorowych modeli korekty błędem (vector error correction model - VECM).

Standardowa postać modelu VAR jest następująca [Ekonometria współczesna 2007]:

$$
X_{t}=A_{0} D_{t}+\sum_{i=1}^{s} A_{i} X_{t-i}+\varepsilon_{t},
$$

gdzie:

$X_{t}$ - wektor obserwacji bieżących wartości analizowanych procesów,

$D_{t}$ - wektor zawierający składniki deterministyczne (np. trend, sezonowość),

$A_{0}$ - macierz parametrów przy składnikach wektora $D_{t}$,

$A_{i}$ - macierz autoregresyjnych operatorów poszczególnych procesów,

$\varepsilon_{t}-$ wektor procesów resztowych,

$s$ - rząd modelu VAR.

Model VAR stosowano w sytuacji braku kointegracji badanych procesów. W przypadku występowania kointegracji szeregów czasowych stosowano wektorowy model korekty błędem.

Ogólny model VECM dla procesów skointegrowanych można przedstawić w następujący sposób [Kusideł 2000]:

$$
\Delta Z_{t}=\Psi_{0} D_{t}+\sum_{i=1}^{s} \Pi_{i} \Delta Z_{t-i}-\Pi Z_{t-1}+\zeta_{t},
$$

gdzie:

$Z_{t}-n$-wymiarowy proces stochastyczny, którego składowe są generowane przez model ARIMA,

$\Psi_{0}$ - macierz współczynników przy składnikach deterministycznych wektora $D_{t}$,

$\Pi_{i}-$ macierz współczynników autoregresji, przy czym $\Pi=I-\sum_{i=1}^{s} \Pi_{i}$,

$\zeta_{t}-n$-wymiarowy proces białoszumowy.

Do identyfikacji związków przyczynowych badanych zmiennych zastosowano test Grangera (wariant Walda). W tym teście z przyczynowością zmiennej X (Y) względem zmiennej Y (X) mamy do czynienia wówczas, gdy łączny wpływ bieżącej zmiennej objaśniającej i opóźnionej zmiennej objaśniającej X (Y) na $\mathrm{Y}(\mathrm{X})$ jest statystycznie istotny. Testowana hipoteza zerowa oznacza więc, że parametry stojące przy zmiennej objaśniającej i jej opóźnieniach są równe zero wobec 
hipotezy alternatywnej, że parametry te istotnie różnią się od zera. Statystyka testu ma postać [Ekonometria współczesna 2007]:

gdzie:

$$
G=\frac{\left(S^{2}\left(\varepsilon_{t}\right)-S^{2}\left(\eta_{t}\right)\right) / q}{S^{2}\left(\eta_{t}\right) /(T-k)}
$$

$S^{2}\left(\varepsilon_{t}\right)$ - wariancja resztowa w modelu bez zmiennej, której przyczynowość jest badana,

$S^{2}\left(\eta_{t}\right)$ - wariancja resztowa w modelu ze zmienną, której przyczynowość jest badana,

$q$ - liczba opóźnień zmiennej objaśniającej,

$T$ - liczebność próby,

$k$ - liczba parametrów w modelu zawierającym zmienną objaśniającą.

Statystyka $G$ przy prawdziwości hipotezy zerowej ma rozkład Fishera-Snedecora o odpowiednio $q$ i $T-k$ stopniach swobody.

Odrzucenie hipotezy zerowej świadczy o tym, że zmienna objaśniająca jest przyczyną w sensie Grangera zmiennej objaśnianej.

\section{Wyniki badań przyczynowości BIZ i wskaźników konkurencyjności polskiego handlu zagranicznego}

Wybór pomiędzy modelami VAR lub VECM stosowanymi do opisu dynamicznych zależności pomiędzy zmiennymi BIZ oraz Ex, RCAs, RCAp, RCAk, RCAt, TC uzależniono od wyników badania stacjonarności i kointegracji odpowiednich szeregów czasowych. Do badania stacjonarności szeregów czasowych zastosowano rozszerzony test Dickeya-Fullera (test ADF) [Ekonometria współczesna 2007]. Wyniki tego testu przedstawiono w tabeli 1 (w nawiasach podano prawdopodobieństwa testowe).

Tabela 1. Wyniki testu ADF dla zmiennych

\begin{tabular}{|c|c|c|c|}
\hline \multirow[b]{2}{*}{ Nazwa zmiennej } & \multirow[b]{2}{*}{$\begin{array}{l}\text { Oznaczenie } \\
\text { zmiennej }\end{array}$} & \multicolumn{2}{|c|}{ Wynik testu ADF dla } \\
\hline & & zmiennej & $\begin{array}{l}\text { pierwszych } \\
\text { przyrostów } \\
\text { zmiennej }\end{array}$ \\
\hline Eksport & EX & $\begin{array}{c}-1,829 \\
(0,0646)\end{array}$ & $\begin{array}{l}-9,3968 \\
(0,0000)\end{array}$ \\
\hline Bezpośrednie inwestycje zagraniczne & $\mathrm{BIZ}$ & $\begin{array}{l}-1,8437 \\
(0,0681)\end{array}$ & $\begin{array}{c}-9,639 \\
(0,0000)\end{array}$ \\
\hline $\begin{array}{l}\text { Wskaźnik przewagi komparatywnej dóbr surow- } \\
\text { cowych }\end{array}$ & RCAs & $\begin{array}{l}-1,3317 \\
(0,1669)\end{array}$ & $\begin{array}{l}-7,7223 \\
(0,0000)\end{array}$ \\
\hline
\end{tabular}


cd. tabeli 1

\begin{tabular}{|c|c|c|c|}
\hline \multirow[b]{2}{*}{ Nazwa zmiennej } & \multirow[b]{2}{*}{$\begin{array}{c}\text { Oznaczenie } \\
\text { zmiennej }\end{array}$} & \multicolumn{2}{|c|}{ Wynik testu ADF dla } \\
\hline & & zmiennej & $\begin{array}{c}\text { pierwszych } \\
\text { przyrostów } \\
\text { zmiennej }\end{array}$ \\
\hline $\begin{array}{l}\text { Wskaźnik przewagi komparatywnej dóbr pra- } \\
\text { cochłonnych }\end{array}$ & RCAp & $\begin{array}{l}-1,4060 \\
(0,1467)\end{array}$ & $\begin{array}{l}-10,516 \\
(0,0000)\end{array}$ \\
\hline $\begin{array}{l}\text { Wskaźnik przewagi komparatywnej dóbr kapita- } \\
\text { łochłonnych }\end{array}$ & RCAk & $\begin{array}{l}-0,6876 \\
(0,4137)\end{array}$ & $\begin{array}{l}-7,5075 \\
(0,0000)\end{array}$ \\
\hline $\begin{array}{l}\text { Wskaźnik przewagi komparatywnej dóbr techno- } \\
\text { logicznie intensywnych }\end{array}$ & RCAt & $\begin{array}{l}-1,0529 \\
(0,2948)\end{array}$ & $\begin{array}{l}-9,8834 \\
(0,0000)\end{array}$ \\
\hline Wskaźnik pokrycia importu eksportem & $\mathrm{TC}$ & $\begin{array}{c}1,5121 \\
(0,9660)\end{array}$ & $\begin{array}{l}-7,0892 \\
(0,0000)\end{array}$ \\
\hline
\end{tabular}

Źródło: obliczenia własne.

Wyniki zamieszczone w tabeli 1 wskazują, że szeregi czasowe zmiennych oryginalnych nie były stacjonarne (prawdopodobieństwa testowe są większe od 0,05 ), natomiast pierwsze przyrosty tych zmiennych są stacjonarne. Szeregi czasowe badanych zmiennych są więc zintegrowane w stopniu pierwszym.

Optymalną liczbę opóźnień zmiennych w modelach ustalono na podstawie kryterium Schwarza [Schwarz 1978], natomiast badanie kointegracji szeregu czasowego BIZ z pozostałymi szeregami czasowymi i wyznaczenie liczby wektorów kointegrujących przeprowadzono, stosując test śladu Johansena [Johansen 1991, 1992]. W tabeli 2 przedstawiono wyniki obu testów wraz z rekomendowanym modelem do badania zależności dla poszczególnych par zmiennych.

Tabela 2. Wyniki testu Schwarza i testu śladu Johansena dla BIZ i wskaźników konkurencyjności handlu zagranicznego

\begin{tabular}{|l|c|c|c|}
\hline \multicolumn{1}{|c|}{ Para zmiennych } & $\begin{array}{c}\text { Optymalna liczba } \\
\text { opóźnień (kryterium } \\
\text { Schwarza) }\end{array}$ & $\begin{array}{c}\text { Liczba wektorów } \\
\text { kointegrujących } \\
\text { (test śladu Johansena) }\end{array}$ & $\begin{array}{c}\text { Rekomendowany } \\
\text { model }\end{array}$ \\
\hline BIZ - Ex & 5 & 0 & VAR \\
\hline BIZ - RCAs & 2 & 1 & VECM \\
\hline BIZ - RCAp & 2 & 1 & VECM \\
\hline BIZ - RCAk & 2 & 0 & VAR \\
\hline BIZ - RCAs & 2 & 1 & VECM \\
\hline BIZ - TC & 2 & 1 & VECM \\
\hline
\end{tabular}

Źródło: obliczenia własne. 
Na podstawie analizy zawartości tabeli 2 można stwierdzić, że w czterech przypadkach szeregi czasowe wykazywały kointegrację (wyniki testu śladu Johansena potwierdziły występowanie jednego wektora kointegrującego). Dla tych par zmiennych oszacowano model VECM. Jedynie w przypadku dwóch par zmiennych przyczynowość w sensie Grangera będzie testowana za pomocą modeli VAR, gdyż test Johansena nie wykazał istnienia kointegracji (są to pary zmiennych: BIZ - Ex i BIZ - RCAk).

Wyniki testu Grangera dla bezpośrednich inwestycji zagranicznych i wszystkich analizowanych zmiennych reprezentujących konkurencyjność handlu zagranicznego przedstawiono w tabeli 3 (wytłuszczono wyniki statystycznie istotne na poziomie istotności równym co najwyżej 0,05$)$.

Tabela 3. Wyniki badania przyczynowości w sensie Grangera pomiędzy bezpośrednimi inwestycjami zagranicznymi i zmiennymi reprezentującymi konkurencyjność handlu zagranicznego w Polsce

\begin{tabular}{|l|c|c|c|}
\hline \multicolumn{1}{|c|}{$\begin{array}{c}\text { Przyczynowość } \\
\text { zmiennych }\end{array}$} & Wynik testu & Wartość $p$ & Model \\
\hline $\mathrm{EX} \rightarrow$ BIZ & 1,5256 & 0,2096 & VAR \\
\hline $\mathrm{BIZ} \rightarrow \mathrm{EX}$ & $\mathbf{2 , 6 5 4 1}$ & $\mathbf{0 , 0 4 0 7}$ & VAR \\
\hline $\mathrm{BIZ} \rightarrow$ RCAs & 1,3591 & 0,2679 & VECM \\
\hline $\mathrm{RCAs} \rightarrow$ BIZ & $\mathbf{6 , 2 7 4 4}$ & $\mathbf{0 , 0 0 4 1}$ & VECM \\
\hline $\mathrm{RCAp} \rightarrow$ BIZ & $\mathbf{4 , 1 2 9 2}$ & $\mathbf{0 , 0 2 3 1}$ & VECM \\
\hline $\mathrm{BIZ} \rightarrow \mathrm{RCAp}$ & $\mathbf{4 , 0 6 3 3}$ & $\mathbf{0 , 0 2 4 4}$ & VECM \\
\hline $\mathrm{BIZ} \rightarrow$ RCAk & 0,2443 & 0,7844 & VAR \\
\hline $\mathrm{RCAk} \rightarrow$ BIZ & 0,7429 & 0,4820 & VAR \\
\hline $\mathrm{BIZ} \rightarrow \mathrm{RCAt}$ & $\mathbf{4 , 7 4 5 3}$ & $\mathbf{0 , 0 1 3 9}$ & VECM \\
\hline $\mathrm{RCAt} \rightarrow \mathrm{BIZ}$ & 0,0991 & 0,9059 & VECM \\
\hline $\mathrm{BIZ} \rightarrow \mathrm{TC}$ & 2,4415 & 0,0993 & VECM \\
\hline $\mathrm{TC} \rightarrow \mathrm{BIZ}$ & $\mathbf{9 , 2 2 3 0}$ & $\mathbf{0 , 0 0 0 5}$ & VECM \\
\hline
\end{tabular}

Źródło: obliczenia własne.

Analizując wyniki w tabeli 3, należy zauważyć, że bezpośrednie inwestycje zagraniczne na poziomie istotności 0,05 są istotną determinantą eksportu, a także są przyczyną konkurencyjności towarów z branży pracochłonnej i technologicznie intensywnej. Sprzężenie zwrotne we wzajemnym oddziaływaniu zmiennych wykryto jedynie w przypadku BIZ i wskaźnika RCAp. Jednocześnie nie stwierdzono istotnej przyczynowości w sensie Grangera w oddziaływaniu BIZ na ujawnioną przewagę komparatywną towarów surowcochłonnych, kapitałochłonnych, jak i na współczynnik pokrycia importu eksportem. Z kolei przyczynami BIZ 


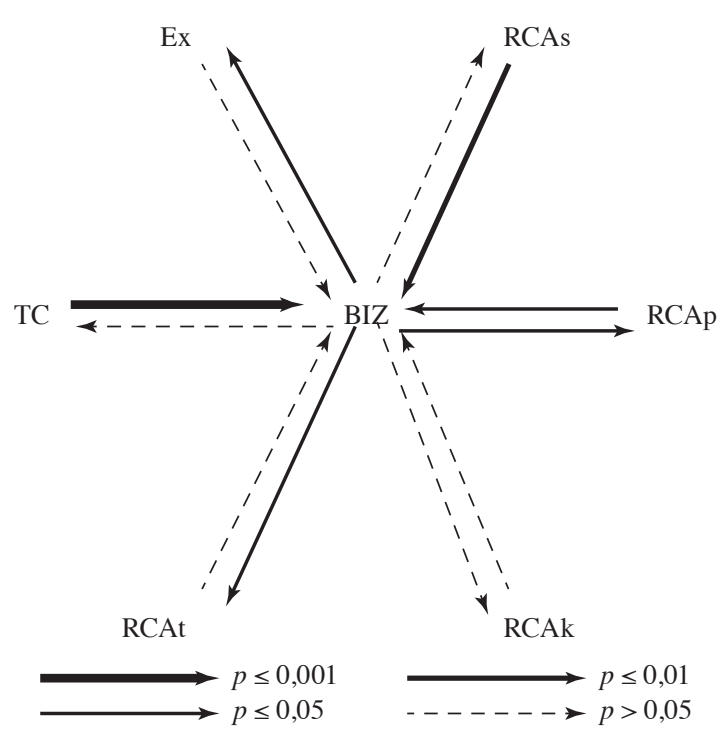

Rys. 1. Schemat zależności przyczynowych w sensie Grangera pomiędzy bezpośrednimi inwestycjami zagranicznymi i zmiennymi reprezentującymi konkurencyjność polskiego handlu zagranicznego

Źródło: opracowanie własne.

(przyczynowość jednokierunkowa) są konkurencyjność towarów surowcochłonnych i wskaźnik pokrycia importu eksportem. Biorąc pod uwagę istotne zależności $\mathrm{BIZ} \rightarrow \mathrm{EX}$ oraz TC $\rightarrow$ BIZ, można stwierdzić, że w gospodarce zarówno BIZ są stymulatorem eksportu, jak i rozmiary eksportu (względem importu) oddziałują na BIZ. Druga z wymienionych zależności może wskazywać, że kondycja polskiego handlu zagranicznego stanowi jedną z przesłanek branych pod uwagę przez inwestorów zagranicznych przy wyborze Polski jako beneficjenta BIZ. Siłę kierunkowych zależności pomiędzy analizowanymi zmiennymi przedstawiono dodatkowo na rys. 1. Najsilniejszy wpływ na BIZ miały wskaźnik pokrycia importu eksportem (wartość $p=0,0005$ ) oraz wskaźnik ujawnionych przewag komparatywnych dób surowcochłonnych (wartość $p=0,0041$ ). Na poziomie istotności 0,05 stwierdzono słabszą dwukierunkową zależność przyczynową pomiędzy BIZ i wskaźnikiem RCAp oraz słabsze jednokierunkowe zależności przyczynowe od BIZ do wskaźnika RCAt i od BIZ w kierunku eksportu. W świetle teorii ekonomii zakładających ewolucyjnych charakter rozwoju gospodarczego [Tarasiński 2009] dominacja BIZ napływających do pracochłonnych gałęzi wytwórczości (BIZ pracochłonne) wskazuje na niską fazę rozwoju gospodarczego, a BIZ w gałęziach technologicznie intensywnych są symptomem wysokiego stadium rozwoju gospo- 
darczego. Otrzymane wyniki można więc uznać za charakterystyczne dla różnych etapów rozwoju gospodarczego. Trudno więc w ich świetle w jednoznaczny sposób zaklasyfikować Polskę do jednej fazy rozwoju gospodarczego.

\section{Wyniki badań przyczynowości komponentów wzorca przewag komparatywnych w Polsce}

W modelu dynamicznych przewag komparatywnych zakłada się, że napływ BIZ prowadzi do ewolucyjnych zmian we wzorcu przewag komparatywnych. Modelowy schemat przeobrażeń tego wzorca jest następujący [Ozawa 1992, Tarasiński 2009]:

- w początkowej fazie rozwoju gospodarczego kraj dysponuje przewagami komparatywnymi w branżach surowcochłonnych,

- z czasem przewagi komparatywne w branżach surowcochłonnych są wypierane przez rosnące korzyści komparatywne w branżach pracochłonnych,

- wzrost przewag komparatywnych wyrobów pracochłonnych z czasem ulega regresowi, natomiast coraz większe znaczenie zyskują przewagi komparatywne w branżach kapitałochłonnych,

- dominacja przewag komparatywnych wyrobów kapitałochłonnych stopniowo zmniejsza się, co jest kompensowane rosnącymi przewagami komparatywnymi w branżach technologicznie intensywnych. Rosnące znaczenie tych ostatnich przewag wskazuje na najwyższy poziom rozwoju gospodarczego.

Wydaje się, że taka „wzorcowa” ewolucja przewag komparatywnych stanowi duże uproszczenie rzeczywistości gospodarczej. Nie można przecież wykluczyć sytuacji, w której kraj wysoko rozwinięty posiada przewagi komparatywne np. w branży surowcochłonnej, jak i technologicznie intensywnej. Możliwe wydają się również wzajemne oddziaływania branż wytwarzających wyroby o różnym stopniu nasycenia czynnikami produkcji. To uzasadnia przeprowadzenie badań wzajemnych powiązań w ujęciu dynamicznym pomiędzy wskaźnikami RCA różnych branż. Pozwoli to na pełniejszą identyfikację zmian we wzorcu przewag komparatywnych i ocenę poziomu konkurencyjności polskiego handlu zagranicznego. W tej analizie również posłużono się metodologią przedstawioną w punkcie 2. Po przeprowadzeniu testu ADF i stwierdzeniu zintegrowania w stopniu pierwszym szeregów czasowych wskaźników RCAs, RCAp, RCAk i RCAt (por. tabelę 1), posługując się testem śladu Johansena, zbadano występowanie kointegracji dla każdej pary szeregów czasowych tych wskaźników, a za pomocą testu Schwarza ustalono optymalną liczę opóźnień badanych zmiennych. Wyniki prezentuje tabela 4. 
Tabela 4. Wyniki testu Schwarza i testu śladu Johansena dla wskaźników przewag komparatywnych

\begin{tabular}{|l|c|c|c|}
\hline \multicolumn{1}{|c|}{ Para zmiennych } & $\begin{array}{c}\text { Optymalna liczba } \\
\text { opóźnień (kryterium } \\
\text { Schwartza) }\end{array}$ & $\begin{array}{c}\text { Liczba wektorów koin- } \\
\text { tegrujących (test śladu } \\
\text { Johansena) }\end{array}$ & $\begin{array}{c}\text { Rekomendowany } \\
\text { model }\end{array}$ \\
\hline RCAs - RCAp & 2 & 1 & VECM \\
\hline RCAs - RCAk & 2 & 1 & VECM \\
\hline RCAs - RCAt & 2 & 1 & VECM \\
\hline RCAp - RCAk & 2 & 1 & VECM \\
\hline RCAp - RCAt & 2 & 1 & VECM \\
\hline RCAk - RCAt & 1 & 0 & VAR \\
\hline
\end{tabular}

Źródło: obliczenia własne.

Tabela 5. Wyniki badania przyczynowości w sensie Grangera pomiędzy wskaźnikami przewag komparatywnych towarów o różnym stopniu nasycenia czynnikami produkcji

\begin{tabular}{|l|c|c|c|}
\hline \multicolumn{1}{|c|}{$\begin{array}{c}\text { Przyczynowość } \\
\text { zmiennych }\end{array}$} & Wynik testu & Wartość $p$ & Model \\
\hline RCAs $\rightarrow$ RCAp & $\mathbf{6 , 5 6 1 2}$ & $\mathbf{0 , 0 0 3 3}$ & VECM \\
\hline RCAp $\rightarrow$ RCAs & 1,9845 & 0,1501 & VECM \\
\hline RCAs $\rightarrow$ RCAk & $\mathbf{4 , 3 5 3 5}$ & $\mathbf{0 , 0 1 9 1}$ & VECM \\
\hline RCAk $\rightarrow$ RCAs & $\mathbf{3 , 7 3 3 6}$ & $\mathbf{0 , 0 3 2 2}$ & VECM \\
\hline RCAs $\rightarrow$ RCAt & $\mathbf{5 , 0 0 0 7}$ & $\mathbf{0 , 0 1 1 3}$ & VECM \\
\hline RCAt $\rightarrow$ RCAs & 0,6051 & 0,5507 & VECM \\
\hline RCAp $\rightarrow$ RCAk & 1,7499 & 0,1862 & VECM \\
\hline RCAk $\rightarrow$ RCAp & $\mathbf{8 , 2 6 9 5}$ & $\mathbf{0 , 0 0 0 9}$ & VECM \\
\hline RCAp $\rightarrow$ RCAt & $\mathbf{4 , 9 7 8 6}$ & $\mathbf{0 , 0 1 1 5}$ & VECM \\
\hline RCAt $\rightarrow$ RCAp & $\mathbf{5 , 0 1 3 3}$ & $\mathbf{0 , 0 1 1 2}$ & VECM \\
\hline RCAk $\rightarrow$ RCAt & 0,4828 & 0,4908 & VAR \\
\hline RCAt $\rightarrow$ RCAk & 0,0371 & 0,8481 & VAR \\
\hline
\end{tabular}

Źródło: obliczenia własne.

Analiza wyników w tabeli 4 pozwala stwierdzić, że skointegrowane były wszystkie pary szeregów czasowych z wyjątkiem jednej pary zmiennych, tj. RCAk i RCAt. Tylko dla tej pary szeregów czasowych oszacowano model VAR, natomiast we wszystkich pozostałych przypadkach - model VECM. Dla znalezienia jedno- oraz dwukierunkowych powiązań pomiędzy przewagami komparatywnymi towarów o różnym stopniu nasycenia czynnikami produkcji przeprowadzono analizę przyczynowości w sensie Grangera na bazie oszacowanych modeli VECM 
i VAR. Rezultaty tej analizy prezentuje tabela 5 (wyniki statystycznie istotne na poziomie istotności równym co najwyżej 0,05 zostały wytłuszczone).

$\mathrm{Z}$ analizy zawartości tabeli 5 wynika, że występują dwa sprzężenia zwrotne w oddziaływaniu przewag komparatywnych wyrobów surowcochłonnych i przewag wyrobów kapitałochłonnych, a także przewag komparatywnych towarów pochodzących z branż pracochłonnych i przewag towarów z branż technologicznie intensywnych. Jednokierunkową przyczynowość w sensie Grangera wykryto w trzech przypadkach: przewagi komparatywne towarów surowcochłonnych są przyczyną przewag komparatywnych towarów pracochłonnych, jak i towarów technologicznie intensywnych, a przewagi komparatywne towarów kapitałochłonnych są przyczyną przewag towarów pracochłonnych. Ta ostatnia zależność może wskazywać, że wzrost konkurencyjności towarów pracochłonnych jest poprzedzony wzrostem konkurencyjności towarów kapitałochłonnych. Siłę zależności przyczynowych w sensie Grangera pomiędzy wskaźnikami przewag komparatywnych przedstawiono także na rys. 2.

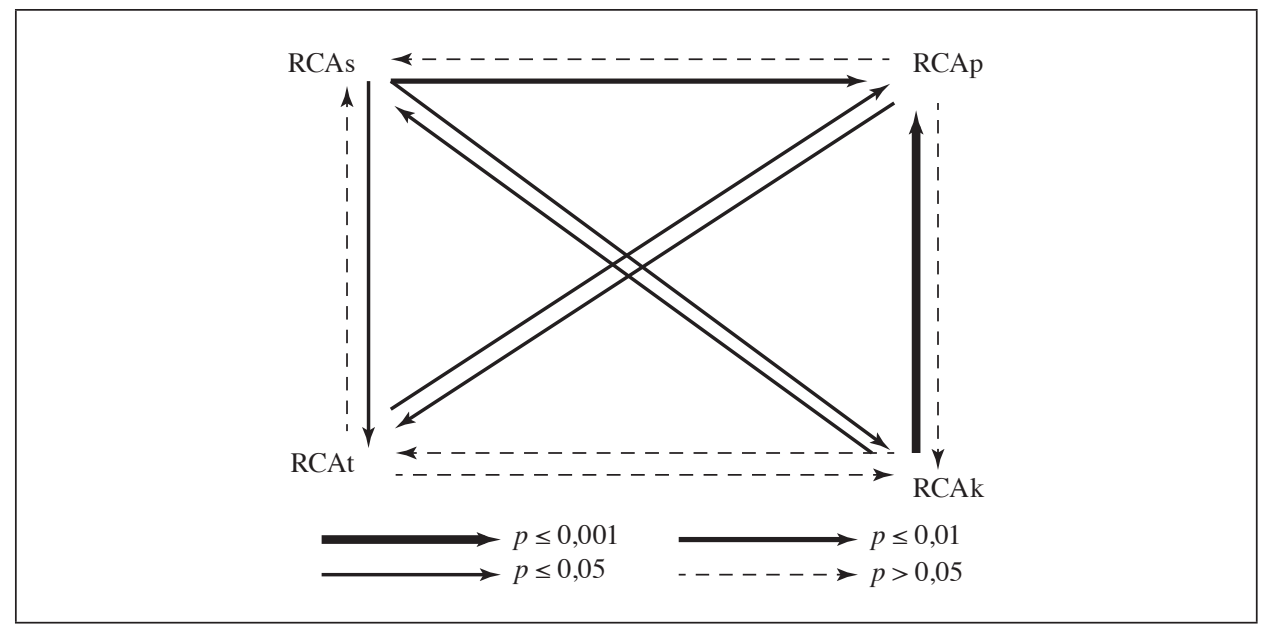

Rys. 2. Schemat zależności przyczynowych w sensie Grangera pomiędzy wskaźnikami przewag komparatywnych towarów o różnym stopniu nasycenia czynnikami produkcji Źródło: opracowanie własne.

Z przedstawionego schematu na rys. 2 wynika, że najsilniejsze przyczynowości mają charakter jednokierunkowy i występują: w kierunku od przewag komparatywnych dóbr kapitałochłonnych do dóbr pracochłonnych (wartość $p=0,0009$ ) oraz w kierunku od przewag komparatywnych dóbr surowcochłonnych do przewag komparatywnych dóbr kapitałochłonnych (wartość $p=0,0033$ ). Dwukierunkowe zależności przyczynowe zachodzące pomiędzy wskaźnikami RCAk i RCAs oraz 
pomiędzy wskaźnikami RCAk i RCAp oraz jednokierunkowa przyczynowość od przewag komparatywnych towarów surowcochłonnych do przewag komparatywnych dóbr kapitałochłonnych są statystycznie istotne na poziomie istotności 0,05 . Dla pozostałych par zmiennych nie zaobserwowano istotnej przyczynowości w żadnym kierunku (na poziomie istotności 0,05 ).

Przedstawione wyniki mogą sugerować, że zależności pomiędzy przewagami konkurencyjnymi towarów o różnym stopniu nasycenia czynnikami produkcji są znacznie bardziej złożone niż przedstawia to model dynamicznych przewag komparatywnych. W teorii ekonomii [Ozawa 1992] przewagę konkurencyjną zyskują branże w następującym porządku: branża surowcochłonna, pracochłonna, kapitałochłonna i technologicznie intensywna, przy czym wzrostowi konkurencyjności towarów jednej branży towarzyszy pogorszenie konkurencyjności towarów należącej do branży o niższym zaawansowaniu technologicznym. Z niniejszych badań wynika, że tylko dla niektórych par branż gospodarki następujących po sobie w sensie ,porządku branż” przewidzianego w modelu wzorca dynamicznych przewag komparatywnych występuje przyczynowość w ujęciu Grangera. Warto odnotować fakt oddziaływania na siebie przewag konkurencyjnych towarów należących do „niesąsiadujących” branż gospodarki (w sensie kolejności branż w modelu T. Ozawy).

\section{Podsumowanie}

W niniejszych badaniach pokazano, że bezpośrednie inwestycje zagraniczne są przyczyną przewag komparatywnych typowych dla różnych faz rozwoju przewidzianych w modelu T. Ozawy [Ozawa 1992]. To utrudnia przypisanie polskiej gospodarki wyłącznie do jednego stadium rozwoju. Wykazano również, że BIZ pobudzają przewagi komparatywne dóbr technologicznie intensywnych, co zgodnie z modelem T. Ozawy lokuje Polskę w wysokiej fazie rozwoju, ale jednocześnie można stwierdzić, że BIZ są przyczyną przewag komparatywnych dóbr pracochłonnych charakterystycznych dla niższego stadium rozwoju. Powiązania pomiędzy komponentami wzorca przewag komparatywnych również mają bardziej złożony charakter niż przewidziano to w modelu T. Ozawy. W świetle otrzymanych wyników można stwierdzić, że przewagi komparatywne typowe dla gospodarek surowcochłonnych pozostają w związku przyczynowym z przewagami komparatywnymi typowymi dla gospodarek wysoko rozwiniętych. Takie wyniki mogą wskazywać, że tempo rozwoju i towarzyszące mu zmiany konkurencyjności różnych działów i sektorów gospodarki polskiej nie są jednakowe. Skutkuje to trudnościami w dopasowaniu konkurencyjności polskiego handlu zagranicznego do modelowego wzorca dynamicznych przewag komparatywnych. 
Jednym z powodów tej sytuacji może być fakt, że model T. Ozawy powstał na bazie doświadczeń gospodarek krajów azjatyckich lat 80. XX w., których struktura i otoczenie ekonomiczne znacząco różniły się od realiów polskiej gospodarki ostatniego dziesięciolecia. Dynamiczne przeobrażenia zachodzące w strukturze polskiej gospodarki m.in. dzięki dostępowi do środków finansowych pochodzących z Unii Europejskiej zapewne będą zmieniały obecny wzorzec konkurencyjności polskiego handlu zagranicznego. Zachodzi więc konieczność kontynuacji badań w przyszłości i aktualizacji ich wyników.

\section{Literatura}

Ekonometria współczesna [2007], red. M. Osińska, Wydawnictwo „Dom Organizatora”, Toruń.

Gurgul H., Lach Ł. [2009], Zwiq̨zki przyczynowe pomiędzy bezpośrednimi inwestycjami zagranicznymi w Polsce a podstawowymi wskaźnikami makroekonomicznymi (wyniki badań empirycznych), „Ekonomia Menedżerska”, nr 6.

Hastiadi F.F. [2011], Regionalism in East Asia: The Role of North East Asian Nations, „American Journal of Economics and Business Administration”, vol. 3(2), http:// dx.doi.org/10.3844/ajebasp.2011.242.253.

Jayanthakumaran K., Lee S.W. [2007], An Initial Push for Successful Transition from Import Substitution to Export-orientation in Taiwan and China: The FDI-led Hypothesis, Faculty of Business - Economics Working Papers, WP 07-03.

Johansen S. [1991], Estimation and Hypothesis Testing of Cointegration Vectors in Gaussian Vector Autoregressive Models, „Econometrica”, vol. 59, nr 6, http://dx.doi. org/10.2307/2938278.

Johansen S. [1992], Determination of Cointegration Rank in the Presence of a Linear Trend, „Oxford Bulletin of Economics and Statistics”, vol. 54, nr 3, http://dx.doi. org/10.1111/j.1468-0084.1992.tb00008.x.

Kusideł E. [2000], Modele wektorowo-autoregresyjne VAR. Metodologia i zastosowania, ABSOLWENT, Łódź.

Misala J. [2011], Międzynarodowa konkurencyjność gospodarki narodowej, PWE, Warszawa.

Misala J., Pluciński E.M. [2000], Handel wewnątrzgałęiowy między Polskq a Uniq Europejskq. Teoria i praktyka, SGH, Warszawa.

Ozawa T. [1992], Foreign Direct Investment and Economic Development, „Transnational Corporation", vol. 1, nr 1.

Salamaga M. [2013], Modelowanie wpływu bezpośrednich inwestycji zagranicznych na handel zagraniczny $w$ świetle wybranych teorii ekonomii na przykładzie krajów Europy Środkowo-Wschodniej, Zeszyty Naukowe, Seria specjalna: Monografie nr 223, Wydawnictwo Uniwersytetu Ekonomicznego w Krakowie, Kraków.

Schwarz G. [1978], Estimating the Dimension of a Model, The Annals of Statistics, vol. 6, nr 2, http://dx.doi.org/10.1214/aos/1176344136.

Sultan Z.A. [2013], A Causal Relationship between FDI Inflows and Export: The Case of India, ,Journal of Economics and Sustainable Development”, vol. 4, nr 2. 
Szymanik E. [2004], Konkurencyjność eksportu na przykładzie wymiany Polski z krajami Unii Europejskiej, Krakowskie Towarzystwo Edukacyjne sp. z o.o., Oficyna Wydawnicza AFM, Kraków.

Tarasiński L. [2009], Bezpośrednie inwestycje zagraniczne a bilans handlowy i struktura przewag komparatywnych [w:] Wpływ bezpośrednich inwestycji zagranicznych na konkurencyjność polskiej gospodarki, red. E. Frejtag-Mika, PWE, Warszawa.

\title{
Identification of Causal Relationships between Foreign Direct Investment and Foreign Trade Patterns in Poland
}

\author{
(Abstract)
}

In the literature there are studies that analyse the impact of foreign direct investment on changes in the pattern of comparative advantage, and on the structure of foreign trade. On the other hand, there are also possible feedback loops, in which the evolution of the pattern of comparative advantage, or the transformation of the structure of foreign trade influences foreign direct investment. So we can ask what the role they have in creating the interactions between variables, or which of these relationships are statistically significant and what is the direction of the impact of variables. The results of Granger causality test can help answer these questions. The aim of this paper was to find causal relationships between foreign direct investment and the variables representing the competitiveness of Polish foreign trade. The study employed vector autoregression models and Granger causality test.

Keywords: foreign direct investment, foreign trade, VAR model, VECM model, Granger causality test. 